seems to the working group to require a list of approved names and synonyms of diseases in one language, together with a definition where this is necessary for comprehension. From these definitions, approved names and synonyms in other languages would be established. The languages used would be English, French, Russian and Spanish, and countries not using them would have to compile the nomenclature for themselves in their own language.

To achieve this, the working group considers that a special CIOMS committee, recommended in a resolution of the seventh general assembly of the organization, should draw up precise guidelines for the preparation of the nomenclature. These would be working rules for groups of specialists within the international organizations who would prepare the different sections of the nomenclature.

\section{Biochemists Federated}

\section{from a Correspondent}

THE annual meetings of the Federation of European Biochemical Societies takes place in rotation in the member countries, and this year's meeting, the fifth, was held in Prague from July 15 to 20 . It was organized by the Czechoslovak Biochemical Society and the Czechoslovak Academy of Sciences, and was attended by some 2,400 biochemists and associate members from nearly all European countries and overseas.

Dr M. F. Perutz gave the first Sir Hans Krebs Lecture on "X-ray analysis, structure and function of crystalline proteins", and a second plenary lecture was given by Dr G. H. Hitchings on "Observations on immunosuppressive drugs". The main part of the meeting consisted of eight symposia and nearly 1,200 free communications arranged in seventeen sections. The symposia covered a wide variety of topics, including relations of enzyme structure and activity; isoenzymes; gamma globulin, its structure and biosynthesis; metabolism of peptide hormones as a factor in hormonal regulation; the application of antimetabolites in biochemical investigations; biochemistry of connective tissue; mitochondria - structure and function; and the hydroxylation of drugs and chemical action of their metabolic products in the organism.

The federation is only four years old, but there are now 23 constituent societies in the federation representing almost every European country. The total membership is more than 14,000 . The federation has launched a second journal, and a generous grant from the Volkswagen Foundation of $£ 15,000$ means that the federation can run its summer school programme for the next three years. There will be two courses this year, one at the University of Edinburgh on the application of computers in biochemistry, and the other at the Weizmann Institute of Science on nucleic acids. Plans for next year are not yet complete, but it is hoped that there will be four courses, one at the University of Groningen on the conformation of biomacromolecules and another at the Max-PlanckInstitut für Meeresforschung at Wilhelmshaven on translation and transcription of genetic information.

At the Prague meeting, the council and executive committee of the federation decided to make arrangements for the loan of teaching films among the interested departments of biochemistry and to set up a bureau for the exchange of protocols of laboratory class experiments. The success of the federation so far in fostering cooperation among biochemists throughout Europe and the scope and success of the Prague meeting indicate that FEBS meetings are likely to acquire a significance for European biochemists comparable with that of the federation meeting in the United States.

\section{Another Federation}

\section{from a Correspondent}

Contacts between British and Continental scientists engaged in connective tissue research were put on an organized basis in Cambridge, between June 30 and July 2, with the formation of a Federation of European Connective Tissue Clubs. Seven clubs, nine nations and 160 individuals took part in a meeting designed to allow the maximum participation by the members. The emphasis was on workshops and discussion, but plenary lectures by $\mathrm{Dr} K$. Kühn (Munich) on "Collagen" and Dr F. Pautard (Leeds) on "Mineralization in biological systems" drew large audiences. Panel discussions on "Protein-polysaccharide interactions" and "Breakdown of connective tissue" organized by Dr J. E. Scott and Dr J. T. Dingle respectively gave four or five main speakers an opportunity to present various aspects of their topic at some length, with interposed discussions. During the workshops, discussion was led by three or more speakers, who were subjected to continuous comment from their audience. Because of the necessity to restrict numbers in each workshop in the interests of good discussion, several were run in parallel, which led to mild complaints that it was impossible to attend everything one would have wished. Workshops were on "Glycoprotein isolation and characterization" (Dr L. Robert, Paris), "Quantitative histology of calcified tissues" (Dr H. A. Sissons, London), "Hexosamine determinations, quantitative and qualitative" (Dr A. Barret, Cambridge), "Status and chemical analysis of collagen fractions from various tissues" (Dr D. S. Jackson, Manchester), and "Mineral assays in calcified tissues" (Dr P. Fourman, Leeds). The British host clubs were the Mucopolysaccharide Club and the Collagen Club, in association with the Bone and Tooth Society. The meeting was organized by Dr J. T. Dingle and Dr J. Reynolds of Cambridge and Dr J. E. Scott of Taplow. It was made possible by financial help from the Wellcome Trust, Ethicon Ltd, and Geigy Ltd.

At a business meeting the clubs agreed to federate, and it was decided to hold the next meeting in Munich in 1970 at the invitation of the German Connective Tissue Club. The current federation representative is Dr J. E. Scott of the MRC Unit, Taplow.

\section{Antarctic Ecology}

\section{from a Correspondent}

ON July 26, Dr L. Gould, the chairman of the Scientific Committee for Antarctic Research, declared open the new extensions to the Scott Polar Research Institute in Cambridge. Throughout the following week the library and lecture theatre were invaded by 150 delegates, mostly from the twelve countries of the Antarctic Treaty, attending the Second Symposium 